Original article

DOI: 10.19027/jai.17.1.34-42

\title{
The application of phytoremediation Lemna perpusilla to increase the production performance of Nile tilapia Oreochromis niloticus in a recirculation system
}

\section{Penggunaan fitoremediasi Lemna perpusilla untuk meningkatkan kinerja produksi ikan nila Oreochromis niloticus pada sistem resirkulasi}

\author{
Rina Hesti Utami ${ }^{1}$, Kukuh Nirmala ${ }^{1 *}$, Iman Rusmana ${ }^{2}$, Daniel Djokosetiyanto ${ }^{1}$, Yuni Puji \\ Hastuti $^{1}$
}

\begin{abstract}
'Department of Aquaculture, Faculty of Fisheries and Marine Science, Bogor Agricultural University ${ }^{2}$ Department of Biology, Faculty of Mathematics and Natural Sciences, Bogor Agricultural University Bogor Agricultural University, West Java, Indonesia
\end{abstract}

(Received 13 Juni 2017; Accepted 12 Maret 2018)

\begin{abstract}
This study aimed to evaluate the production performance and physiological of Nile tilapia using Lemna perpusilla as a phytoremediator in a recirculation system. A completely randomized design with two treatments and three replications was applied. The treatments were Nile tilapia cultured with $L$. perpusilla (TL) and without $L$. perpusilla (L). The experimental fish in this study was the juvenile of Nile tilapia with a body length of $9.98 \pm 0.08 \mathrm{~cm}$ and an average weight of $36.27 \pm 1.07 \mathrm{~g}$. The stocking density was $46 \mathrm{fish} /$ pond and the container size was $275 \times 100 \times 60$ $\mathrm{cm}^{3}$ and was separated in two areas using a fiber separator screen of $55.9 \%$ area for fish culture and $44.1 \%$ for L. perpusilla. The Nile tilapias were reared for 60 days, fed with commercial diet and fresh L. Perpusilla with amount $2 \%$ and $1 \%$ of biomass, respectively. They were fed three times a day with fresh $L$. perpusilla at noon and commercial diet in the morning and afternoon. The results showed that the Nile tilapia reared with L. perpusilla phytoremediation had normal physiological condition and production performance. The predominances of this system were lower feed conversion ratio value, more optimal values of feeding efficiency, and higher coefficient of weight uniformity.
\end{abstract}

Keywords: Lemna perpusilla, physiological condition, phytoremediation, production performance.

\begin{abstract}
ABSTRAK
Penelitian ini bertujuan mengevaluasi kinerja produksi dan fisiologi ikan nila dengan penggunaan Lemna perpusilla sebagai fitoremediator pada sistem resirkulasi. Rancangan penelitian yang digunakan adalah acak lengkap dengan dua perlakuan dan tiga ulangan. Ikan nila dipelihara pada kolam tanpa L. perpusilla (TL) dan ikan nila dipelihara pada kolam dengan L. perpusilla (L). Ikan yang digunakan dalam penelitian ini adalah benih ikan nila dengan panjang baku 9,98 $\pm 0,08 \mathrm{~cm}$ dan bobot rata-rata 36,27 $\pm 1,07 \mathrm{~g}$. Padat tebar ikan tiap kolam pemeliharaan 46 ekor/kolam dengan ukuran kolam $275 \times 100 \times 60 \mathrm{~cm}^{3}$. Setiap kolam diberi sekat dengan luasan $44,1 \%$ L. perpusilla dari luasan kolam. Ikan nila dipelihara selama 60 hari pemeliharaan dengan pakan berupa pakan komersial dan $L$. perpusilla dengan jumlah pakan masing-masing $2 \%$ dan $1 \%$ dari biomassa. Pada pagi dan sore hari diberi pakan komersial, dan siang hari ikan diberi pakan L. perpusilla. Hasil penelitian ini menunjukkan bahwa ikan nila yang dipelihara dengan fitoremediasi $L$. perpusilla menghasilkan kinerja produksi dan kondisi fisiologis yang normal. Keunggulan sistem ini adalah menghasilkan nilai konversi pakan yang lebih rendah, nilai efisiensi pemberian pakan, dan koefisien keseragaman bobot yang lebih tinggi.
\end{abstract}

Kata kunci: fitoremediasi, Lemna perpusilla, kondisi fisiologis, kinerja produksi. 


\section{INTRODUCTION}

The intensive tilapia Oreochromis niloticus rearing will also support by increased feeding. The common problem on Nile tilapia rearing is an excessive waste, especially nitrogen $(\mathrm{N})$ and phosphorus (P), caused by uneaten feed and metabolism waste (Lazzari \& Baldisserotto, 2008). The waste in rearing media will pollute water quality and growth performance so that it will lead to profit loss. One of the solution to overcome kind of situation is using recirculation system. The recirculation system potentially reduces water renewal, rearing waste, and overcome water and land availability limitation (Delong et al., 2009; Martins et al., 2010; Zhang et al., 2011; Van Rijn, 2012). The principal of recirculation system is reuse of the rearing media by recirculating the rearing media in the certain system. The effect of using recirculation system is waste accumulation along with fish growth will cause dissolved oxygen decreasing (Schreier et al., 2010). The solution to reducing the side effect of using recirculation system is combining recirculation system and phytoremediation.

Phytoremediation application using aquatic plant has already used in aquaculture (Velichkova \& Sirakov, 2013). One of the aquatic plant used as phytoremediator is Lemna perpusilla (Ferdoushi, 2008; Amalia et al., 2014). In this study, L. perpusilla is applied as phytoremediator and additional feed for Nile tilapia. The study by Tavares et al. (2010) reported that utilization of $L$. valdiviana Phil. in red tilapia rearing as water quality treatment and additional feed. $L$. perpusilla biomass was applied as an alternative feed for Nile tilapia because it potentially substituted commercial feed as many of $25 \%$ with the protein content of $38.10 \%$ (Ilyas et al., 2014). This study aimed to evaluate production performance and physiology of Nile tilapia with phytoremediator L. perpusilla application in a recirculation system. The outcome of this study is expected to be applied in eco-friendly Nile tilapia rearing.

\section{MATERIALS AND METHODS}

\section{Experimental design}

This study was conducted using randomized complete design with two treatments and three replication. The treatments were TL (without $L$. perpusilla) and $\mathrm{L}$ (phytoremediation using $L$. perpusilla) and the container scheme is showed in Figure 1.

\section{Rearing container}

The Nile tilapia rearing container was concrete pond covered by a $275 \times 100 \times 60 \mathrm{~cm}^{3}$ tarp. The pond was cleaned, covered with a tarp and then filled with $0.9 \mathrm{~m}^{3}$ of reservoir water each pond. Water renewal was not conducted, however, to maintain water height caused by evaporation, water addition was conducted. Each pond was

\section{$\mathrm{L}$ (phytoremediation using Lemna perpusilla)}

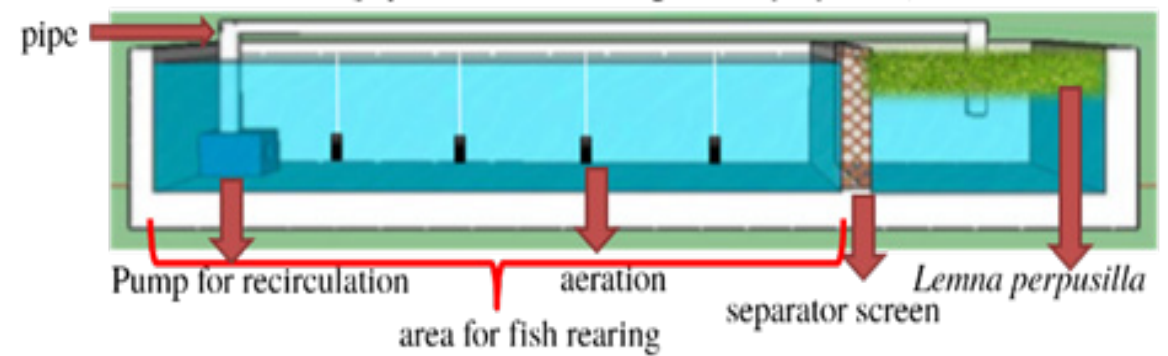

(a)

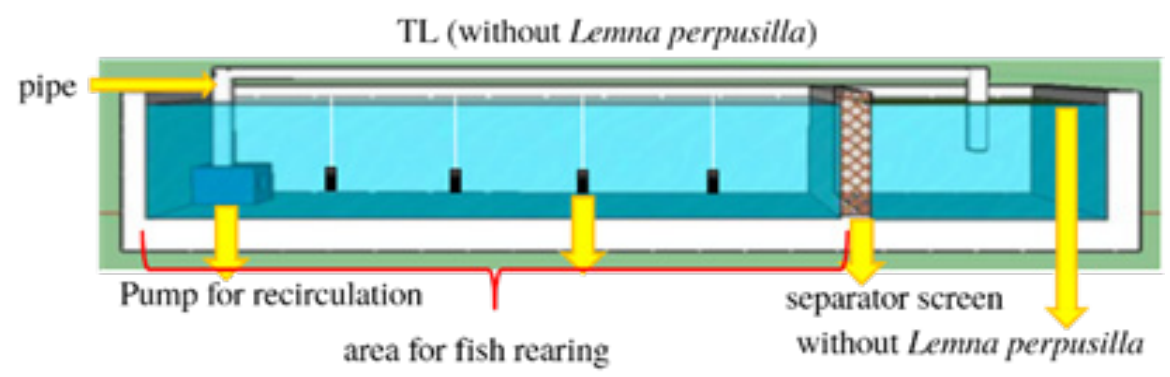

(b)

Figure 1. Treatment scheme in experiment activity: (a) L (with Lemna perpusilla) treatment and (b) TL (without Lemna perpusilla) 
Table 1 . The water quality parameter

\begin{tabular}{lccc}
\hline \multicolumn{1}{c}{ Water quality parameter } & Unit & Instrument & $\begin{array}{c}\text { Measurement } \\
\text { method }\end{array}$ \\
\hline $\mathrm{pH}$ & - & $\mathrm{pH}$-meter & (APHA, 1995) \\
Temperature & ${ }^{\circ} \mathrm{C}$ & Thermometer & (APHA, 1995) \\
Dissolved oxygen & $\mathrm{mg} / \mathrm{L}$ & DO-meter & (APHA, 1995) \\
Brightness & $\mathrm{cm}$ & Secchi disk & (APHA, 1995) \\
Turbidity & $\mathrm{NTU}$ (nephalometric & Turbidimeter & (APHA, 1995) \\
& turbidity units) & & \\
Hardness & $\mathrm{mg} / \mathrm{L} \mathrm{CaCO} 3$ & Titration & (APHA, 1995) \\
Alkalinity & $\mathrm{mg} / \mathrm{L} \mathrm{CaCO}$ & Titration & (APHA, 1995) \\
Total organic matter $(\mathrm{TOM})$ & $\mathrm{mg} / \mathrm{L}$ & Titration & (APHA, 1995) \\
Total ammonia nitrogen $(\mathrm{TAN})$ & $\mathrm{mg} / \mathrm{L}$ & Spectrophotometer & (APHA, 1995) \\
\hline
\end{tabular}

equipped with aeration installation and internal recirculation. A plastic bulkhead separator was placed inside the pond at a distance about $44.1 \%$ of the total pond extent (Amalia et al., 2014).

\section{The experimental fish and aquatic plant}

The experimental fish was the Nile tilapia juvenile with average length $9.98 \pm 0.08 \mathrm{~cm}$ and an average weight $36.27 \pm 1.07 \mathrm{~g}$. The stock density was 50 fishes $/ \mathrm{m}^{3}$ (Gibtan et al., 2008). The Nile tilapia juvenile was acquired from the experimental pond of Aquaculture Department, Faculty of Fisheries and Marine Science, Bogor Agricultural University. The experimental aquatic plant was L. Perpusilla with initial stock density based on the placement of the plastic bulkhead separator at $44.1 \%$ of total pond extent (Amalia et $a l ., 2014)$. The aquatic plant $L$. perpusilla was also used as additional feed. According to proximate analysis, the protein content of commercial diet and L. perpusilla were $33.07 \%$ and $31.86 \%$, respectively.

\section{The rearing activity}

The rearing activity of the Nile tilapia was conducted for 60 days. During the rearing activity, the Nile tilapia was fed using commercial feed (pellet) and fresh L. perpusilla with feeding rate $1 \%$ and $2 \%$ from the fish biomass, respectively (Gibtan et al., 2008). The feeding frequency was done three times a day, in the morning, in the afternoon, and in the evening. In the morning and evening, the fishes were fed using pellet, while in the afternoon using the fresh L. perpusilla.

\section{The experimental parameter}

The experimental parameter in this study consisted of water quality, physiological respond, and growth performance of the experimental fish. The water quality was measured in situ every day and the parameters were temperature, $\mathrm{pH}$, and dissolved oxygen (Zhou et al., 2009). The weekly measured water quality consisted of the brightness, total organic matter (TOM), turbidity, hardness, and alkalinity (Azim \& Little, 2008) (Table 1).

The sample collection for the growth and physiological respond (blood glucose and lysozyme activity) was conducted every 20 days (Braun et al., 2010). The blood glucose level analysis was done using CHOD-PAP (enzymatic colorimetric test for glucose method with deproteinization) with glucose liquicolor kit in brand Human. The equation to analize the blood glucose is showed below:

$$
\text { Blood glucose }(\mathrm{mg} / \mathrm{dL})=\frac{\text { sample absorbant }}{\text { blank absorbant }} \times 100
$$

The lysozyme activity analysis was started with liquid suspension addition of Micrococcus lysodeikticus (Sigma) bacteria as many of 100 $\mu \mathrm{L}(0.4 \mathrm{mg} / \mathrm{mL})$ in $0.1 \mathrm{M}$ of phosphate buffered saline pH 6.2 into blood plasma sample $(100 \mu \mathrm{L})$ in $25{ }^{\circ} \mathrm{C}$. The absorbant was read twice in 450 $\mathrm{nm}$ wavelength on the microplate reader for 30 seconds, 15 minutes, 30 minutes, 45 minutes, and 60 minute of the blending. The lysozyme activity unit would be limited in certain amount of enzyme which caused the absorbant decreasing $0.001 /$ minute. The equation of lysozyme activity is showed below:

$$
\text { Lysozyme activity }(\text { unit } / \mathrm{mL})=\frac{\frac{(\text { initial OD-final OD) } \times 100}{\text { Final time measurement }}}{\text { sample volume }}
$$

The production performance parameter was measured through the fish growth (fish length and body weight) every 20 days (Braun et al., 2010). The production performance parameter consisted of the absolute length, feed convertion ratio, feeding efficiency, survival rate, and the coefficient of length and body weight variance. 
Specific length growth rate

The measurement of specific growth rate was calculated using below equation (Effendie, 1997):

$$
\alpha \mathrm{p}=(\mathrm{Lt} / \mathrm{Lo})^{1 / 2} \mathrm{t}-1
$$

Note:

ap : specific length growth rate ( $\mathrm{cm} /$ day)

Lt : average body length in certain time (cm)

Lo : initial average body length $(\mathrm{cm})$

$\mathrm{T} \quad$ : rearing period (days)

Absolute length growth (PPM)

Absolute length growth was calculated using this following equation (NRC, 1983):

$$
\mathrm{PPM}=\mathrm{Pt}-\mathrm{Po}
$$

Note :

PPM : absolute length growth $(\mathrm{cm})$

$\mathrm{Pt} \quad$ : average body length in certain time (cm)

Po : initial average body length $(\mathrm{cm})$

Specific growth rate (SGR)

Specific growth rate is stated through the equation below (Schulz et al., 2005):

Note :

$$
\mathrm{SGR}=\left(\ln \mathrm{W}_{\mathrm{t}}-\ln \mathrm{W}_{\mathrm{o}}\right) / \mathrm{t} \times 100
$$

$\mathrm{SGR}=$ specific growth rate $(\%)$

$\mathrm{W}_{\mathrm{t}} \quad=$ average body weight in certain time $(\mathrm{g})$

$\mathrm{W}_{\mathrm{o}} \quad$ = initial average body weight $(\mathrm{g})$

$\mathrm{t} \quad=$ rearing period (hari)

Absolute growth (PM)

Absolute growth is calculated using this equation below (Effendie, 1997):

Note :

PM = absolute growth (g/day)

$\mathrm{Wt}=$ average body weight in certain time (g)

Wo = initial average body weight $(\mathrm{g})$

$\mathrm{t} \quad=$ rearing period (day)

\section{Feed conversion ratio (FCR)}

FCR is calculated using the equation according to Goddard (1996):

$$
\mathrm{FCR}=\mathrm{F} /((\mathrm{Wt}+\mathrm{Wd})-\mathrm{Wo})
$$

Note :

FCR : feed convertion ratio
Wt : final fish biomass (g)

Wo : biomass of dead fish during the experiment $(\mathrm{g})$

Wd : initial fish biomass (g)

$\mathrm{F} \quad$ : total mount of feed during the experi ment (g)

Feeding efficiency (EPP)

Feeding efficiency is calculated using the equation according to Li et al. (2010):

$$
\operatorname{EPP}(\%)=\frac{\mathrm{B}_{\mathrm{t}}-\mathrm{B}_{0}+\mathrm{Bm}}{\mathrm{t}}
$$

Note :

$\begin{array}{ll}\text { EPP } & \text { : feeding efficiency }(\%) \\ \mathrm{Pa} & \text { : total feed consumption }(\mathrm{g}) \\ \mathrm{Bt} & \text { : weight biomass in certain time }(\mathrm{g}) \\ \mathrm{B} 0 & \text { : initial weight biomass }(\mathrm{g}) \\ \mathrm{Bm} & \text { : dead fish biomass }(\mathrm{g})\end{array}$

Survival rate (TKH)

The survival rate of experimental fish was calculated using the equation below (Goddard, 1996):

$$
\mathrm{TKH}=\frac{\mathrm{N}_{\mathrm{t}}}{\mathrm{N}_{\mathrm{o}}} \times 100
$$

Note :

TKH : survival (\%)

$\mathrm{Nt} \quad$ : final fish population

No : initial fish population

\section{Coefficient of length and body weight variance} (KK)

The equation of the coefficient of variance was calculated according to Steel and Torrie (1993) :

$$
\mathrm{CV}=\frac{\mathrm{S}}{\mathrm{Y}} \times 100
$$

Note :

KK : coefficient of variance (\%)

$\mathrm{S} \quad$ : standard deviation

$\mathrm{Y} \quad$ : sample average

\section{Data analysis}

All the datas were analyzed using t-test with confidence interval 95\% in Minitab 16.0. Descriptive analysis was used to analyzed the water quality parameter.

\section{RESULTS AND DISCUSSIONS}

\section{Results}

Growth performance

Data analysis using t-test showed that $L$. perpusilla application as phytoremediator on recirculation system had significant difference 
Table 2. The production performance of Nile tilapia in TL (without L. perpusilla) and L (with L. perpusilla) treatment.

\begin{tabular}{lcc}
\hline \multicolumn{1}{c}{ Production performance parameter } & Treatment \\
\cline { 2 - 3 } & TL & $\mathrm{L}$ \\
\hline Spesific length growth rate (cm/fish/day) & $0.409 \pm 0.13^{\mathrm{a}}$ & $0.471 \pm 0.06^{\mathrm{a}}$ \\
Absolute length growth (cm) & $0.64 \pm 0.23^{\mathrm{a}}$ & $0.75 \pm 0.09^{\mathrm{a}}$ \\
Specific growth rate (\%/day) & $1.00 \pm 0.61^{\mathrm{a}}$ & $1.24 \pm 0.23^{\mathrm{a}}$ \\
Absolute growth rate (g/fish/day) & $0.49 \pm 0.33^{\mathrm{a}}$ & $0.65 \pm 0.15^{\mathrm{a}}$ \\
Feed convertion ratio (FCR) & $2.64 \pm 0.06^{\mathrm{a}}$ & $2.31 \pm 0.071^{\mathrm{b}}$ \\
Feeding efficiency (\%) & $37.94 \pm 0.86^{\mathrm{a}}$ & $43.38 \pm 1.3^{\mathrm{b}}$ \\
Survival rate (\%) & $100.00 \pm 0.00^{\mathrm{a}}$ & $99.46 \pm 0.18^{\mathrm{b}}$ \\
Weight coefficient of variance (\%) & $19.26 \pm 1.10^{\mathrm{a}}$ & $15.98 \pm 0.41^{\mathrm{b}}$ \\
Length coefficient of variance (\%) & $7.05 \pm 1.10^{\mathrm{a}}$ & $5.67 \pm 0.32^{\mathrm{a}}$ \\
\hline
\end{tabular}

Note: The same superscript indicates no significant difference between treatments $(\mathrm{P}>0.05)$

towards FCR, EPP, and CV of weight $(\mathrm{P}<0.05)$. The other production performance parameters consisted of specific length growth, absolute length growth, absolute growth rate, and length coefficient of variance, showed no significant difference among treatments ( $>0.05$; Table 2$)$.

\section{Blood glucose}

The result of $\mathrm{t}$-test indicated that the addition of $L$. perpusilla did not affect blood glucose level of Nile tilapia significantly (Figure 2). The blood glucose level of Nile tilapia in TL and L treatments ranged from $81.09-110.87 \mathrm{mg} / \mathrm{dL}$ and $69.81-99.01 \mathrm{mg} / \mathrm{dL}$ respectively.

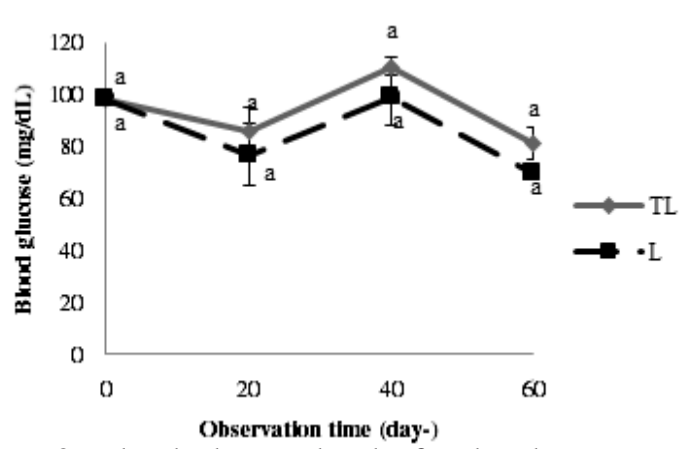

Figure 2. Blood glucose level of Nile tilapia on TL (without L. perpusilla) and L (with L. perpusilla) during the rearing period. The similar superscript indicates no significant difference through t-test with $5 \%$ of significance level.

\section{Lysozyme activity}

The result of t-test showed that $L$. perpusilla addition did not affect lysozyme activity significantly. The increasing of lysozyme activity occurred at all treatments in the day-20, then the lysozyme activity at all treatments decreased until the end of the experiment (Figure 3)

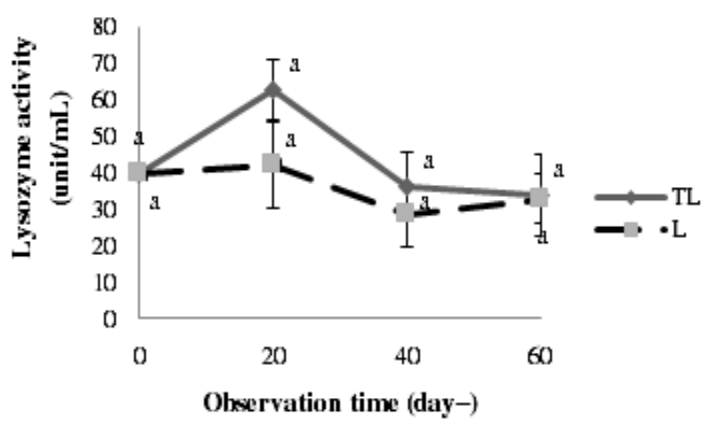

Figure 3. Lysozyme activity on Nile tilapia with TL (without L. perpusilla) and L (phytoremediation using L. perpusilla) during the rearing period. The same superscript letter at the same observation time indicates non significant result through t-test with 5\% of the significant level.

\section{Temperature and $\mathrm{pH}$ level of rearing media}

The $\mathrm{L}$ treatment had higher $\mathrm{pH}$ level and temperature compared to the TL treatment. The $\mathrm{pH}$ level range of $\mathrm{TL}$ and $\mathrm{L}$ treatments were 7.32-7.79 and 7.51-7.79 respectively. The temperature of TL treatment was ranged from $28.07-30.60^{\circ} \mathrm{C}$, while the temperature of $\mathrm{L}$ treatment was ranged from $28.27-30.17^{\circ} \mathrm{C}$. The decreasing of rearing media temperature has the similar tendency with the decreasing of $\mathrm{pH}$ level. The decreasing of temperature was occurred at day-14 until day-28, while at day-42 until the end of the experiment (Figure 4).

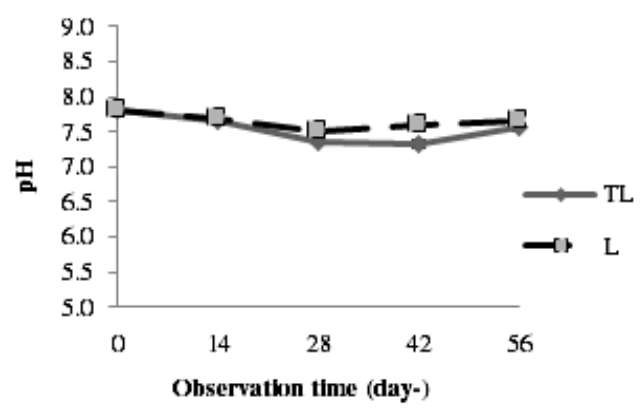

(a) 


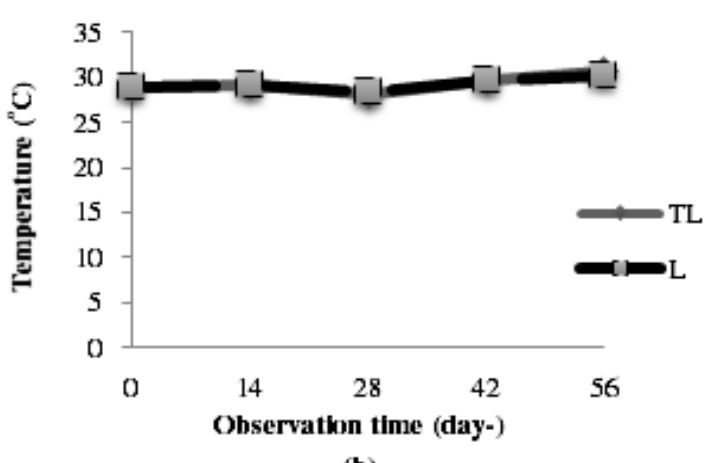

(b)

Figure 4. $\mathrm{pH}$ (a); water temperature (b) with TL (without L. perpusilla) and L (phytoremediation with L. perpusilla) during the rearing period.

\section{Water brightness and turbidity}

The water brightness in the $\mathrm{L}$ treatment was higher than the TL treatment, while the turbidity in the L treatment was lower than the TL treatment. The water brightness and turbidity have an inversely proportional correlation with the water brightness parameter. The higher turbidity gets, the water brightness will decrease. In the $\mathrm{L}$ treatment, the turbidity fluctuation was more stable than the TL treatment (Figure 5)

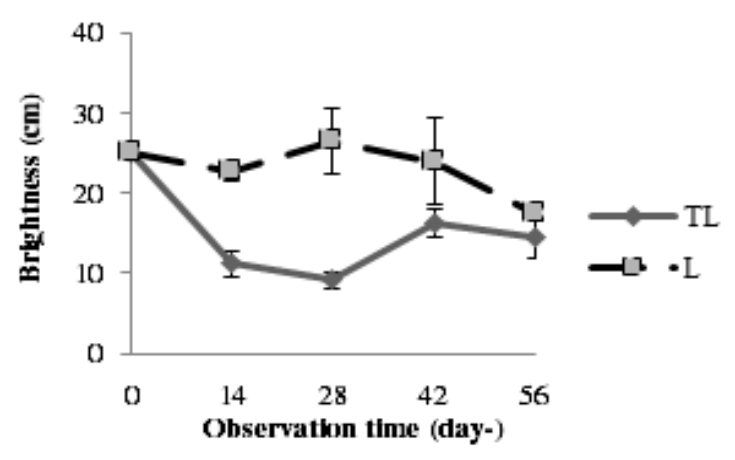

(a)

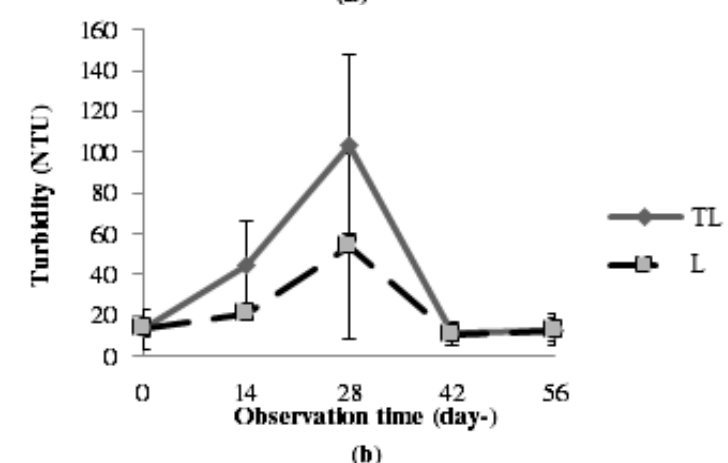

Figure 5. Brightness (a); turbidity (b) with TL (without $L$. perpusilla) and $\mathrm{L}$ (phytoremediation using $L$. perpusilla) during the rearing period.

Dissolved oxygen and total organic matter (TOM)

Overall, the dissolved oxygen in all treatments showed a decreasing trend during the rearing period. The TL treatment had the higher dissolved oxygen $(4.74-5.87 \mathrm{mg} / \mathrm{L})$ compared to the $\mathrm{L}$ treatment $(4.21-5.83 \mathrm{mg} / \mathrm{L})$. The TOM concentration in both treatments had inversely proportional correlation with the dissolved oxygen (Figure 6).

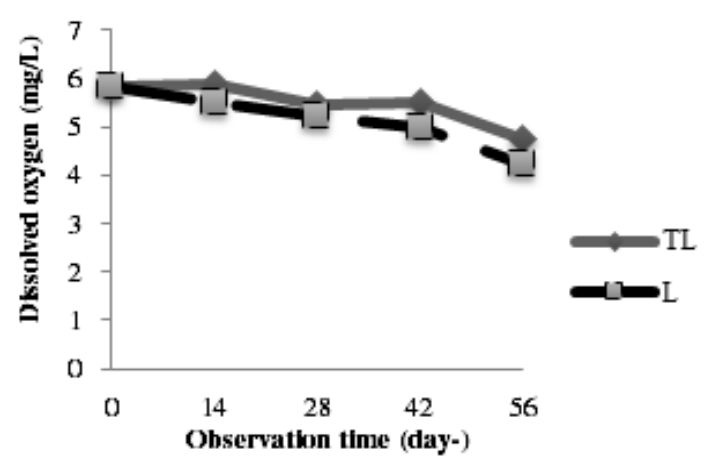

(a)

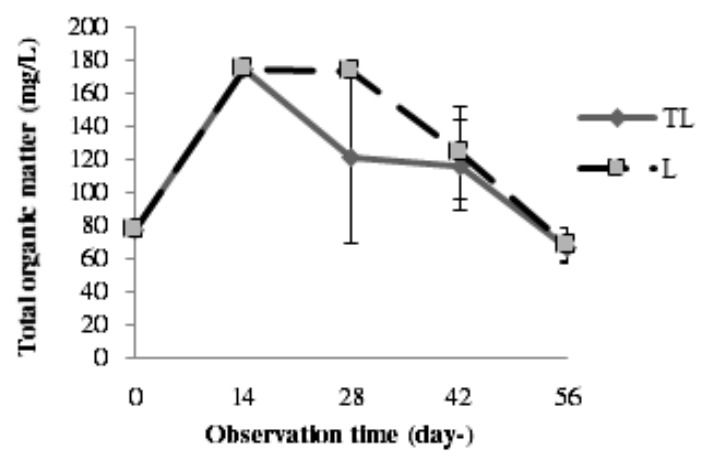

(b)

Figure 6. Dissolved oxygen (a); and total organic matter (TOM) (b) in the TL (wihout L. perpusilla) and $\mathrm{L}$ treatment (phytoremediation L. perpusilla) during the rearing period.

\section{Hardness and alkalinity}

The water hardness and alkalinity during the rearing period were increasing in both treatments. Overall, the TL treatment had a lower range in the alkalinity and hardness parameters compared with the L treatment (Figure 7). The hardness of the TL treatment ranged from $5.40-13.35 \mathrm{mg} / \mathrm{L}$, while the L treatment ranged from 5.40-16.95 $\mathrm{mg} / \mathrm{L}$. The alkalinity of TL treatment ranged from $39.69-89.31 \mathrm{mg} / \mathrm{L} \mathrm{CaCO}_{3}$ which lower than the $\mathrm{L}$ treatment which ranged from $39.69-121.37 \mathrm{mg} / \mathrm{L}$ $\mathrm{CaCO}_{3}$.

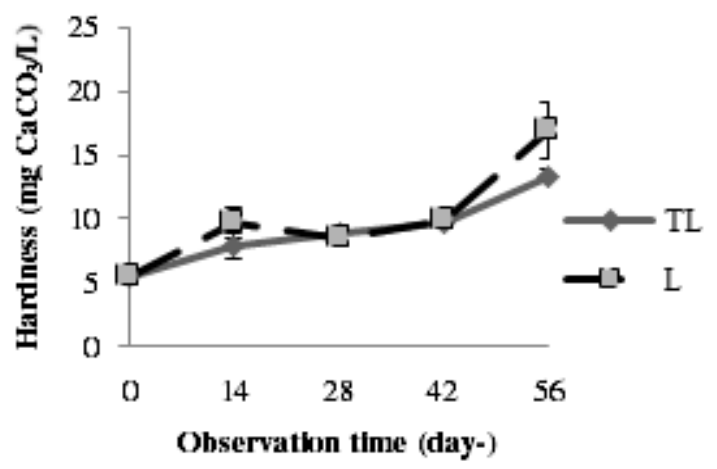

(a) 


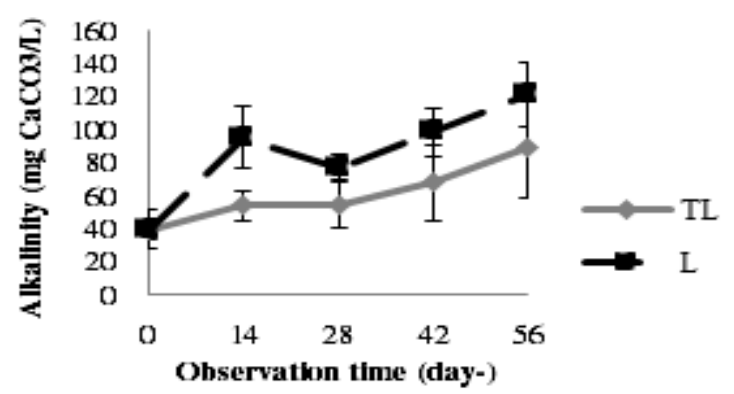

(b)

Figure 7. Water hardness (a); and alkalinity (b) in the TL (without L. perpusilla) and L treatment (phytoremediation with $L$. perpusilla) during the rearing period

\section{Total ammonia nitrogen (TAN)}

The total ammonia nitrogen (TAN) in the rearing media was decreased since day-14 until day -42 and tend to decrease until the end of the experiment. The range of TAN value in TL treatment $(0.113-0.616 \mathrm{mg} / \mathrm{L})$ was lower than the $\mathrm{L}$ treatment (0.081-0.646 mg/L) (Figure 8).

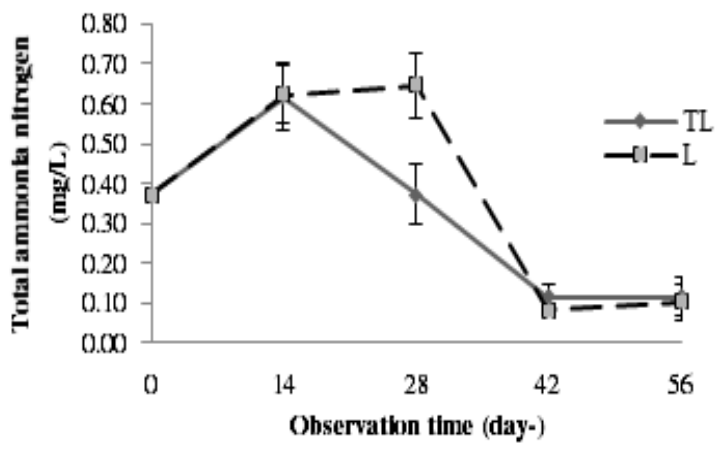

Figure 8. Total ammonia nitrogen (TAN) in the TL (without L. perpusilla) and L treatment (phytoremediation with $L$. perpusilla) during rearing the period.

\section{Discussion}

The production performance using $L$. perpusilla as phytoremediator in the recirculation system did not affect the absolute and specific growth rate, length growth rate (specific and absolute), and length coefficient of variance were not also affected significantly $(\mathrm{P}>0.05)$. The predominance of recirculation system had lower FCR, feeding efficiency, and higher in the weight uniformity. It was complied with the experiment by Velichkova and Sirakov (2013) which stated that Lemna minor and Wolffia arrhiza application in a recirculation system resulted in better FCR and increased the growth performance of Nile tilapia.

The physiological respond of the fish by using L. perpusilla as phytoremediator in a recirculation system did not affect lysozyme activity and blood glucose level significantly. There were no disease-infected fishes during the rearing period.
It was an indicator that the lysozyme activity between treatments was not significantly different. Lysozyme held an important role in nonspecific immunity or innate immunity (Saurabh \& Sahoo, 2008). The blood glucose level was also no significant difference between treatments. It was assumed that environmental factors, such as temperature and dissolved oxygen, were slightly on the similar range. The blood glucose level of Nile tilapia will increase significantly along with the water temperature increasing (Mirea et al., 2013). The increasing of blood glucose will occur when the fish is lack of oxygen (EL-Khaldi, 2010).

The blood glucose level of the experimental Nile tilapia in the TL and $\mathrm{L}$ treatments were still in normal condition. Roques et al. (2010) reported that the blood glucose of the experimental Nile tilapia in normal condition ranges from $32-137 \mathrm{mg} / \mathrm{dL}$. The result of blood sugar level of the Nile tilapia described that all the experimental fishes were not suffered from stress condition. Sanches et al. (2015) also reported that the decreasing of blood glucose in Nile tilapia is secondary stress respond indicator.

The predominance of using $L$. perpusilla as phytoremediator in a recirculation system was supported by the other water quality parameter. The $\mathrm{pH}$ value and temperature in the TL and L treatment were within the tolerance range. The optimum $\mathrm{pH}$ value and temperature during a rearing period were $7-8$ and $27-32^{\circ} \mathrm{C}$ respectively (El-Sherif \& El-Feky, 2009; Pandit \& Nakamura, 2010).

The turbidity value describes the turbid level of an aquatic environment. The higher turbidity gets, the waste load of rearing activity is also get higher. The turbidity value in the TL treatment was higher than the L treatment. It is in accordance with the experiment by Vanitha et al. (2015) which reported that the application of macrophyte could decrease the water turbidity level. The brightness level has inversely correlation with the turbidity level. The brightness level in the L treatment was higher than the TL treatment. It was in accordance with the experiment by Estlander et al. (2009) which stated that the water brightness was influenced by the density of macrophyte, if the macrophyte density was low, the water brightness would also low.

The dissolved oxygen in the $\mathrm{L}$ treatment was lower than the TL treatment. It was caused by total organic matter (TOM) in the L treatment was higher than the TL treatment. It was caused by the decomposing process by $L$. perpusilla because it needs a high level of dissolved oxygen (Zhu et al., 2011). The organic matter in aquaculture system consisted of rotten algae, uneaten feed, and bacteria community (Boyd et 
al., 2016). Nevertheless, the dissolved oxygen condition in the $\mathrm{L}$ and TL treatment was in optimum condition. The optimum dissolved oxygen to support the survival of Nile tilapia was ranged from 3-5.6 mg/L (Colt et al., 2011).

The water hardness described the concentration of $\mathrm{Ca}^{2+}$ and $\mathrm{Mg}^{2+}$ cation, while the alkalinity described the concentration of ion $\mathrm{HCO}_{3}{ }^{-}, \mathrm{CO}_{3}{ }^{2-}$, and $\mathrm{OH}^{-}$(Boyd et al., 2016). The concentration of hardness and alkalinity in all treatments during the rearing period was in the optimum condition. According to De Holanda Cavalcante et al. (2009), the optimum water hardness and alkalinity to support the growth performance of Nile tilapia were $>50$ and $>140 \mathrm{CaCO}_{3} \mathrm{mg} / \mathrm{L}$. The high level of alkalinity in the $\mathrm{L}$ treatment was caused various factors, such as high level $\mathrm{pH}$ and ammonium. The increasing of $\mathrm{pH}$ value will follow by ion $\mathrm{CO}_{3}{ }^{2-}$ and $\mathrm{HCO}_{3}-$ (Boyd et al., 2016). The range of total ammonia nitrogen in all treatments is $2.58-2.63 \mathrm{mg} / \mathrm{L}$, compared to the experiment by Nakphet et al. (2017). The total ammonia nitrogen in the $\mathrm{L}$ treatment was decreased at the end of the experiment. It was assumed that total ammonia nitrogen was utilized by L. perpusilla. Chaudhary and Sharma (2014) also Zhao et al. (2014) stated that aquatic plant L. minor was potentially reduced ammonium waste $\left(\mathrm{NH}_{4}{ }^{+}\right)$in water and utilized it to grow.

\section{CONCLUSION}

Application of L. perpusilla as phytoremediator in a recirculation system was able to generate a better production performance with a normal physiological condition with some of the predominances were a lower feed conversion ratio, better in feeding efficiency, and high level of uniformity in weight.

\section{REFERENCES}

Amalia F, Nirmala K, Haris E, Widiyanto T. 2014. The capabilities of minute duckweed Lemna perpusilla Torr as fitoremediator to absorb nitrogen waste in walking catfish Clarias gariepinus culture resirculation system. Limnotek-Perairan Darat Tropis di Indonesia 21: 185-192.

Azim ME, Little DC. 2008. The biofloc technology (BFT) in indoor tanks: water quality, biofloc composition, and growth and welfare of Nile tilapia Oreochromis niloticus. Aquaculture 283: 29-35.

[APHA]. 1995. Standard methods for the examination of water and wastewater.
Washington DC: APHA (American Public Health Association), AWWA (American Water Works Association) and WPCF (Water Pollution Control Federation).

Boyd CE, Tucker CS, Somridhivej B. 2016. Alkalinity and hardness: critical but elusive concepts in aquaculture. Journal of the World Aquaculture Society 47: 1-36.

Braun N, Lima RL, Baldisserotto B, Dafre AL, Nuñer APO. 2010. Growth, biochemical, and physiological responses of Salminus brasiliensis with different stocking densities and handling. Aquaculture 301: 22-30.

Chaudhary E, Sharma P. 2014. Use of duckweed in wastewater treatment. International Journal of Innovative Research in Science, Engineering and Technology 3: 13622-13624.

Colt J, Momoda T, Chitwood R, Fornshell G, Schreck C. 2011. Water quality in tilapia transport: from the farm to the retail store. North American Journal of Aquaculture 73: 426-434.

De Holanda Cavalcante D, De Sousa Poliato A, Castro Ribeiro D, Batista Magalhães F, do Carmo e Sá MV. 2009. Effects of $\mathrm{CaCO}_{3}$ liming on water quality and growth performance of fingerlings of Nile tilapia, Oreochromis niloticus. Animal Sciences 31: 327-333.

Delong DP, Losordo TM, Rakocy JE. 2009. Tank culture of tilapia. Southern Regional Aquaculture Center. SRAC Publication 282: $1-8$.

Effendie MI. 1979. Metode Biologi Perikanan. Bogor: Yayasan Dewi Sri.

El-Khaldi AT. 2010. Effect of different stress factors on some physiological parameters of Nile tilapia Oreochromis niloticus. Saudi Journal of Biological Sciences 17:241-246.

El-Sherif MS, El-Feky AMI. 2009. Performance of Nile tilapia Oreochromis niloticus fingerlings. I. effect of $\mathrm{pH}$. International Journal of Agriculture \& Biology 11: $297-$ 300.

Estlander S, Nurminen L, Olin M, Vinni M, Horppila J. 2009. Seasonal fluctuations in macrophyte cover and water transparency of four brown-water lakes: implications for crustacean zooplankton in littoral and pelagic habitats. Hydrobiologia 620: 109-120.

Ferdoushi Z, Haque F, Khan S, Haque M. 2008. The Effects of two aquatic floating macrophytes (Lemna and Azolla) as biofilters of nitrogen and phosphate in fish ponds. Turkish Journal of Fisheries and Aquatic Sciences 8: 253-258.

Gibtan A, Getahun A, Mengistou S. 2008. Effect of stocking density on the growth performance 
and yield of Nile tilapia Oreochromis niloticus L., 1758 in a cage culture system in Lake Kuriftu, Ethiopia. Aquaculture Research 39: 14501-460.

Goddard S. 1996. Feed Management in Intensive Aquaculture. New York: Chapman and Hall.

Ilyas AP, Nirmala K, Harris E, Widiyanto T. 2014. Use of Lemna perpusilla as a combination feed for tilapia Oreochromis niloticus in recirculation system. Limnotek-Perairan Darat Tropis di Indonesia 21: 193-201.

Lazzari R, Baldisserotto B. 2008. Nitrogen and phosphorus waste in fish farming. Boletim do Instituto de Pesca 34: 591-600.

Li MH, Robinson EH, Oberle DF, Lucas PM. 2010. Effects of various corn distillers byproducts on growth, feed efficiency, and body composition of channel catfish, Ictalurus punctatus. Aquaculture Nutrition 16: 188193.

Martins CIM, Eding EH, Verdegema MCJ, Heinsbroek LTN, Schneider O, Blancheton JP, Roque d'Orbcastel E, Verreth JAJ. 2010. New developments in recirculating aquaculture systems in Europe: a perspective on environmental sustainability [review]. Aquacultural Engineering 43: 83-93.

Mirea CC. 2013. Hematological characterization of Nile tilapia Oreochromis niloticus, Linnaeus, 1758 reared intensively in a recirculating aquaculture system in relation to water temperature. Scientific Papers Animal Science and Biotechnologies 462: 234-237.

Nakphet S, Ritchie RJ, Kiriratnikom S. 2017. Aquatic plants for bioremediation in red hybrid tilapia Oreochromis niloticus $\times$ Oreochromis mossambicus recirculating aquaculture. Aquaculture International 25: 619-633.

[NRC] National Research Council. 1983. Nutrient requirement of warmwater fishes and shellfishes. Washington DC: National Academy of Science.

Pandit NP, Nakamura M. 2010. Effect of high temperature on survival, growth and feed convertion ratio of Nile tilapia, Oreochromis niloticus. Our Nature 8: 219-224.

Roques JA, Abbink W, Geurds F, van de Vis H, Flik G. 2010. Tailfin clipping, a painful procedure: studies on Nile tilapia and common carp. Physiology \& Behavior 101: 533-540.

Sanches FHC, Miyai CA, Pinho-Neto CF, Barreto RE. 2015. Stress responses to chemical alarm cues in Nile tilapia. Physiology \& Behavior 149: 8-13.

Saurabh S, Sahoo PK. 2008. Lysozyme: an important defence molecule of fish innate immune system. Aquaculture Research 39: 223-239.

Schreier HJ, Mirzoyan N, Saito K. 2010. Microbial diversity of biological filters in recirculating aquaculture systems [current opinion]. Biotechnology 21: 318-325.

Schulz C, Knaus U, Wirth M, Rennert B. 2005. Effect of varying dietary fatty acid profile on growth performance, fatty acid, body and tissue composition of juvenile pike perch Sander lucioperca. Aquaculture 11: 403-413.

Steel RGH, Torrie JH. 1993. Prinsip dan Prosedur Statistika. Jakarta: Gramedia Pustaka Utama.

Tavares F, Lapolli FR, Roubach R, Jungles MK, Fracalossi DM, Moraes AM. 2010. Use of domestic effluent through duckweeds and red tilapia farming in integrated system. PanAmerican Journal of Aquatic Sciences 5: $1-10$.

Vanitha S, Nampoothiri N, Sivapragasam C. 2015. Effect of covering of macrophytes, detention time on improving water quality. International Journal of ChemTech Research 8: 175-182.

Van Rijn J. 2012. Waste treatment in recirculating aquaculture systems. Aquacultural Engineering 53: 49-56.

Velichkova KN, Sirakov IN. 2013. The usage of aquatic floating macrophytes Lemna and Wolffia as biofilter in recirculation aquaculture system (RAS). Turkish Journal of Fisheries and Aquatic Sciences 13: 101-110.

Zhang SY, Li G, Wu HB, Liu XG, Yao YH, Tao L, Liu H. 2011. An integrated recirculating aquaculture system (RAS) for land-based fish farming : the effects on water quality and fish production. Aquacultural Engineering 45: 93-102.

Zhou XX, Wang YB, Li WF. 2009. Effect of probiotic on larvae shrimp Penaeus vannamei based on water quality, survival rate and digestive enzyme activities. Aquaculture 287: 349-353.

Zhao Z, Shi H, Liu Y, Zhao H, Su H, Wang M, Zhao Y. 2014. The influence of duckweed species diversity on biomass productivity and nutrient removal efficiency in swine wastewater. Bioresource technology 167: 383-389.

Zhu ZY, Zhang J, Wu Y, Zhang YY, Lin J, Liu SM. 2011. Hypoxia off the Changjiang (Yangtze River) estuary: oxygen depletion and organic matter decomposition. Marine Chemistry 125: 108-116. 